\title{
A Novelist Observation on Emotional Deprivation During the First World War
}

\section{Birinci Dünya Savașı Sırasında Bir Roman Yazarının Duygusal Yoksunlukla Ilișkili Gözlemi}

\author{
Nejat Akar \\ TOBB-Economy and Technology University Hospital, Clinic of Pediatrics, Ankara, Turkey
}

Key words: Emotional deprivation, first world war, memory

Anahtar Kelimeler: Sevgi yoksunluğu, birinci dünya savaşı, anı

Conflicts of Interest: The author reported no conflict of interest related to this article.

Halide Edip Adıvar was a Turkish novelist and nationalist and feminist political leader. In her memories dealing with the First World War, she remembers an infant at an orphanage in Lebanon. These orphanages were established by the Turks for the Arab, Armenian, Kurdish and Turkish orphan children. These orphanages were supported not only by the army, but also by the Americans, or rich families. The students at these schools included hundreds of Armenian, Arab, Kurdish, and Turkish orphans. She was invited by the Cemal Pasha, commander of the Ottoman Army for to act as an inspector for schools in Damascus, Beirut and the Collège Saint Joseph in Mount Lebanon.

During her visits, she met a girl in one of the orphanage. She saw her on three different occasions one year apart. In her memories she depicts her first and second acquaintances (1).

"There was one child among the small ones for whom I was destined to take a keen, even painful interest. She was the youngest there. I had seen her first as one of the sickly tattered crowd of children during the previous year. She had a dirty chemise which covered only a part of her little body; shaking her unkempt curls, she was looking about her with intense curiosity in her little eyes, blazing with passion and will-power. She hardly spoke any language well, but she jabbered in a mixture of Turkish and Kurdish, putting in Armenian and Arabic words now and then. Her name was Jale, which means Dewdrop in literary Turkish, but the name had evidently been given to her by some one in the school; no such name could be given to an Anatolian child. She had been immediately taken up by Sister Ismet, the Turkish nurse, who gave her all her spare moments, and the little girl had conceived a great passion for her in return. She was now one of the gayest and the healthiest children. I knew the reason; she had found in this way a human kinship; if all the rest could each have been adopted by one special woman."

Later on, she went once more to Lebanon to the orphanage in Aintoura. She continues her observations:

"I had gone to stay for a longer spell in the little Montessori class. This time the little ones looked brighter and better, except one little girl who was morose, sickly, and miserable beyond description. All the other children held 
each other's hands, sang, and turned round gaily, while she walked listlessly. It was months since I had met such a sickly child in Aintoura, so I went to her and taking her thin cheeks gently in my hands, I lifted her face to mine. It was that of Jale, the happiest and healthiest child some months ago.

"Why don't you sing, Jale?"

"I have no more a mother."

Sister Ismet had caught a bad form of malaria, and as it had affected her lungs for the time being, she was removed to a higher place in Lebanon. And it was that separation which had brought Jale into this shocking state. Fortunately I had known to the full in my own life the effect of moral distress on childish sensitiveness.

"You come and be my guest in Beirut sometime.

Your mother will be getting well before long," I said.
"You will be my mother," she said, as if deciding on something which depended only on her."

Halide Edip later on took Jale to Istanbul, wanted to adopt her, but she had trachoma in her eyes so she had to leave her to another orphanage in Istanbul.

Emotional deprivation known as psychosocial dwarfism, and maternal deprivation dwarfism is an important cause of growth retardation. This case report excerpted from the memories of Halide Edip, is an important historical observation on the psychosocial development or health on children during war times.

\section{Reference}

1. Adıvar, Halide Edip, Memoirs of Halidé Edib. John Murray.1926. 